\title{
OTWARTOŚĆ NA INNEGO. TWÓRCZE ORIENTACJE ŻYCIOWE W PROJEKCIE EDUKACJI MIĘDZYKULTUROWEJ
}

Preferencje dla twórczych orientacji życiowych sprzyjają konstruowaniu takiego projektu tożsamościowego, który relacje z Innym i dialogiczne z nim współistnienie czyni istotnym warunkiem rozwoju indywidualnego i społecznego. W założeniach autorskiej koncepcji twórczych orientacji życiowych wpisana jest otwartość na Innego w trzech przestrzeniach narracji: ontologicznej wyrażającej się w dialogice i filozofii spotkania, psychologicznej, której istotą jest teoria twórczości codziennej oraz pedagogicznej, kreowanej przez racjonalność emancypacyjną i pedagogikę twórczości. Koncepcja twórczych orientacji życiowych wpisuje się zatem w holistyczne ujęcie edukacji międzykulturowej opartej na paradygmacie współistnienia, tolerancji i dialogu oraz twórczym kreowaniu własnej tożsamości. Twórcze orientacje życiowe traktuję jako specyficzny, głęboko osobisty i w pełni zaangażowany sposób pełnienia codziennych obowiązków w życiu. Mają one charakter emancypacyjny i dialogiczny, kształtują się w relacji człowieka ze światem, w procesie zdobywania podmiotowości i wolności, w dialogu z Innym. Wpisują się w dynamiczne ujęcie struktury człowieka jako istoty in statu nascendi. Twórczość codzienna jest koniecznością w dynamicznie zmieniającym się świecie. Wymagana jest dzisiaj od uczniów, studentów, nauczycieli, pracowników nowoczesnego rynku pracy, polityków i przedsiębiorców. Od dawna jest obecna w teleologii edukacji jako ważny cel procesów kształcenia i wychowania. Nie może więc jej zabraknąć w edukacji międzykulturowej. Jest niezbędna w rozumieniu odmienności i perspektywy Innego. Rozumienie oznacza uświadomienie sobie istotnych związków między rzeczami i faktami, zdawanie sobie z czegoś sprawy, wnioskowanie o czymś, interpretowanie czegoś [Słownik... 1998: 269]. Staje się ono twórcze, wówczas gdy przekracza perspektywę obserwacyjną i w toku tego procesu podmiot staje się zdolny do kreowania rzeczywistości, rozumienia Innych, ale nie zatraca przy tym własnego, specyficznego widzenia świata. 
Takie odczytanie kategorii twórczego rozumienia wywodzące się z koncepcji postawy etycznej „niewspółobecności” Michaiła Bachtina [1986] pozwala wpisywać je w transgresyjno-transcendentalną perspektywę poznawczą [Kozielecki 1987; 1997; 2001]. Rozumienie w tym ujęciu ewoluuje od elementarnego do wyższego, nabiera charakteru krytycznego i przez dostrzeganie różnych horyzontów staje się rozumieniem twórczym, takim, które wzbogaca rzeczywistość o nowe sensy i znaczenia. Twórcze orientacje życiowe umożliwiają twórcze rozumienie Innego.

\section{Teoretyczne założenia koncepcji twórczych orientacji życiowych}

Koncepcję twórczych orientacji życiowych, którą sformułowałam i rozwijam od kilkunastu lat, konstruuję w układzie trzech płaszczyzn odniesienia, opisanych szczegółowo w książce Kształtowanie twórczych orientacji $\dot{z} y$ ciowych w procesie edukacji [Cudowska 2004; 2014]. W płaszczyźnie ontologicznej wpisuję ją w ideę homo explorens „człowieka poszukującego”, który postrzega siebie myślącego, poznającego i przekształcającego rzeczywistość, doświadcza swojej ontycznej aktywności, zdobywa świadomość swojej kreacyjnej roli, a ta umożliwia mu „umyślną twórczość”. Świadomość i samoświadomość otwierają szansę na zamierzone wzbogacanie siebie, a w konsekwencji twórcze realizowanie i kreowanie własnego, niepowtarzalnego stylu życia. Uprawomocnienia koncepcji twórczych orientacji życiowych upatruję w filozofii dialogu, którą buduje metafizyka orientacji, poszukującą sensu bycia poza teoretycznymi kategoriami, w uczestnictwie i zaangażowaniu, a jej podstawą czyni dialog [Schnädelbach 2001; Szulakiewicz 2003].

Psychologiczną płaszczyznę koncepcji twórczych orientacji życiowych opisuje ujęcie zaproponowane przez psychologów humanistycznych, którzy twórczość wiążą nie tyle z wytworem, ile ze stylem życia. Twórczy potencjał jest przypisywany każdej jednostce, ale jego rozwój wymaga sprzyjających warunków, stąd proces samorealizacji jest udziałem niewielu ludzi. Niezwykle ważne w określeniu twórczych orientacji jest także postrzeganie twórczości w psychologii kultury, gdzie jest ona ujmowana jako indywidualny wybór, interpretacja i restrukturyzacja pojmowania świata w taki sposób, że wiąże się to z codziennym doświadczeniem jednostki. Analizuje ona funkcjonowanie twórcy w określonym środowisku, uwzględniając proces tworzenia, osobowość kreatywną i wytwór. 
Pedagogiczną płaszczyznę koncepcji twórczych orientacji życiowych konstruuje teoria twórczości codziennej. W literaturze obecne są trzy ujęcia twórczości egalitarnej: Ruth Richards [1999; Richards i in. 1997; cyt. za: Świgulska 2009], Marca Runco [2005; 2006; cyt. za: Świgulska 2009] i Anny Craft [2000; cyt. za: Świgulska 2009]. W psychologii i pedagogice odróżnia się ją od twórczości elitarnej, wybitnej. Twórczość powszechna dokonuje się w wymiarze subiektywnym, osobistym i jest wyrazem określonego stylu życia. Jednocześnie odnosi się do szerokiego rozumienia kultury, wykraczającego poza jej artystyczne postrzeganie [Kłoskowska 1964]. W treść takiego ujęcia twórczości wpisuje się zarówno osobowość twórcza, jak i wytwory twórczości, czyli produkty, idee, zachowania, wynikające $z$ codziennej aktywności człowieka we wszystkich sferach jego życia, od pracy zawodowej po czas wolny [Richards 1999]. Twórczość codzienna wiąże się z potrzebą rozwoju, przekształcania środowiska, przetrwania w różnych warunkach, poszukiwaniem sensu życia, fenomenologicznym przeżywaniem i doświadczaniem codzienności. Wynika ona $\mathrm{z}$ realizacji zadań rozwojowych, rozwiązywania problemów i projektowania własnej przyszłości. W tym sensie jest więc własnością człowieka i jest powszechna, jak powszechne jest uczestnictwo ludzi w kulturze, zróżnicowane jednak co do specyfiki, intensywności, charakteru, rodzaju i znaczenia. Twórczość codzienna jest wpisana w proces samorealizacji jednostki

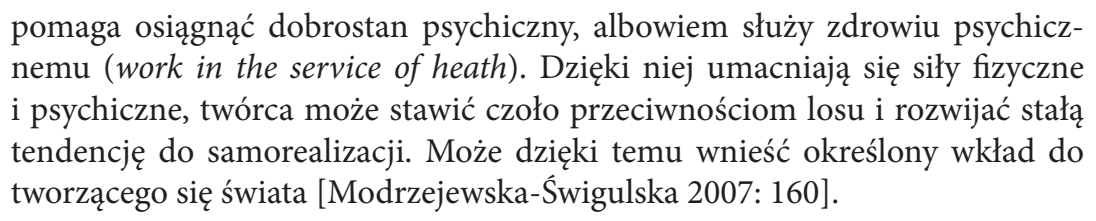

Taki właśnie stosunek do życia przejawiający się w twórczych postawach, podejmowaniu nowych zadań, oryginalnym rozwiązywaniu problemów, uznawaniu twórczości za wartość, chęci urzeczywistniania własnego potencjału rozwojowego, gotowości ciągłego uczenia się i doskonalenia w codziennym życiu jest wyrazem twórczych orientacji życiowych ${ }^{1}$.

Koncepcja twórczych orientacji życiowych wpisuje się także w szeroko rozumiany przedmiot zainteresowań pedagogiki twórczości, określony przez Krzysztofa J. Szmidta jako poszukiwanie i analiza teoretyczna oraz empiryczna edukacyjnych uwarunkowań rozwoju kreatywności dzieci, młodzieży i dorosłych. Sytuuje się także w obszarze pomocy w tworze-

$1 \quad$ Szerzej zagadnienia te opisuję w najnowszej pracy z tego zakresu [Cudowska 2014]. 
niu, rozumianej jako budzenie oraz wspieranie zdolności twórczych ludzi w każdym wieku. Tworzenie dotyczy tu życia codziennego, rozwiązywania problemów osobistych i społecznych, podejmowania wyzwań i nowych zadań, realizacji własnego potencjału rozwojowego, stawiania sobie realnych celów i osiągania ich poprzez aktywne, twórcze uczestnictwo w kulturze i w życiu społeczności².

Wyeksponowanie twórczości codziennej i wsparcia jednostki w jej urzeczywistnianiu posiada szczególny walor w koncepcji twórczych orientacji życiowych, przenosi bowiem akcenty $\mathrm{w}$ analizie tego zjawiska, ze szczególnych uzdolnień i predyspozycji na samoświadomość jednostki. Domeną takiej twórczości są wszystkie formy i dziedziny ludzkiej aktywności, a nie tylko wybrane obszary kultury. Polega ona na generowaniu wytworów i zachowań nowych oraz wartościowych dla działającego podmiotu, zakotwiczona jest w świadomości aksjologicznej jednostki. Walor subiektywności nie umniejsza w żaden sposób znaczenia tej aktywności dla podmiotu jak i społeczności, w której on funkcjonuje pomnażając, poprzez swoją twórczą postawę, jej dobrostan.

Duże znaczenie dla rozumienia twórczych orientacji posiada także perspektywa emancypacyjna [Czerepaniak-Walczak 2006], która eksponuje osiąganie nowych jakości w świecie życia przez osobiste przeżycie, odwagę dopuszczenia do głosu własnej perspektywy, przy jednoczesnym poszanowaniu i twórczym rozumieniu perspektywy Innego ${ }^{3}$. Wpisują się one także w dynamiczne ujęcie struktury człowieka jako istoty, która się staje, obecne w filozofii Józefa Tischnera i modelu paidei wyłaniającego się $\mathrm{z}$ niej w formie pedagogii agatologicznej. Jej fundamentalnym założeniem

$\overline{2}$ Takie ujęcie zaproponowali polscy pedagodzy społeczni Kazimierz Korniłowicz i Helena Radlińska w latach trzydziestych XX wieku. Było to trzydzieści lat przed słynnym już wystąpieniem Paula J. Guilforda, którym zainicjował zainteresowanie psychologów twórczością i na długo przed koncepcjami amerykańskich psychologów humanistycznych, m.in. Carla R. Rogersa, Abrahama H. Maslowa, Roberta J. Mayo i Ericha Fromma, którzy wskazywali potrzebę wspierania rozwoju twórczego potencjału każdego człowieka [Korniłowicz 1976; Radlińska 1979; Szmidt 2002].

3 Szerzej uzasadniam tę tezę w pracy [Cudowska 2014], wskazuję w tym kontekście na kompetencje emancypacyjne jako wyuczaną i dynamiczną sprawność podmiotu wyrażającą się w dostrzeganiu i rozumieniu ograniczeń i deprywacji, świadomym wyrażaniu niezgody na nie, obieraniu dróg ich pokonania i osiągania nowych praw i pól wolności oraz odpowiedzialnego korzystania $\mathrm{z}$ nich w celu doskonalenia siebie i otoczenia; działania podmiotu w świecie codziennym, współtworzenie procesu zmiany własnej sytuacji społecznej i historycznej; oraz racjonalność emancypacyjną, jako sprawność intelektualną, która umożliwia uzasadnianie własnej perspektywy myślowej, krytyczną ocenę zdarzeń i sytuacji ograniczających oraz projektowanie działań sprzyjających osiąganiu zamierzonych celów. 
jest przekonanie, że człowiek rodzi się z dobra, a budowanie człowieczeństwa to wybieranie tego, co dobre [Tischner 1993; 2000] ${ }^{4}$.

\section{Specyfika twórczych orientacji życiowych}

Twórcze orientacje życiowe (TOŻ) ${ }^{5}$ są specyficznym, głęboko osobistym i w pełni zaangażowanym sposobem pełnienia codziennych obowiązków w życiu. Cechuje je: świadomość i celowość własnych działań, zdolność i chęć podejmowania nowych zadań, poczucie sprawstwa i kontroli wobec sytuacji zewnętrznych, podejmowanie nowych wyzwań, wypróbowywanie różnych sposobów radzenia sobie w sytuacjach trudnych, świadoma działalność na rzecz samorozwoju, wzbogacanie własnej osobowości, nabywanie nowych doświadczeń i umiejętności, poczucie wolności moralnej i autonomia sądów oceniająco-wartościujących jednostki, refleksyjność i podmiotowe zakorzenieniem $\mathrm{w}$ bycie, odpowiedzialność za wspólne dobro.

Twórcze orientacje życiowe są specyficzne dla danej osoby, nie ma bowiem dwóch takich samych sposobów na urzeczywistnianie kreatywnych orientacji. Podstawowym imperatywem kształtowania się orientacji życiowej jest świadomość dokonywanych wyborów i podejmowanie trudu samostanowienia. Orientacje życiowe w kreatywnym wymiarze są aksjo-

4 Metafora rodzenia się człowieka jest bliska, proponowanemu przeze mnie, ujęciu bycia człowieka $\mathrm{w}$ świecie, jako homo explorens, istoty poszukującej zakorzenienia w bycie przez twórcze odczytanie i przekształcanie rzeczywistości. Stawanie się człowieka oznacza wydobywanie na wierzch, rozświetlanie czegoś, co jest na razie niewidoczne, ale może zostać ujawnione w procesie realizacji twórczego potencjału w imię ideałów wspólnego dobra [por. Cudowska 2004: 263-269].

5 Szerzej zagadnienie to prezentuję we wspomnianych już pracach [Cudowska 2004; 2014]. Wyjaśniam tu również pojęcie orientacji życiowych, ich uwarunkowań, oraz przedstawiam autorskie rozumienie tej kategorii, które po raz pierwszy opisałam w pracy [Cudowska 1997]. Orientacje życiowe ujmuję jako kategorię opisową, dynamiczną, o charakterze procesualnym. Jest ona zjawiskiem złożonym w płaszczyźnie interpersonalnej i intrapersonalnej, w obrębie wyborów dokonywanych przez człowieka w różnych okresach jego życia. Podstawę jej określenia stanowi ustosunkowanie się jednostki do wartości egzystencjalnych. Jest to więc względnie stały, ale też podlegający ewolucji, zespół poglądów i przekonań na temat potrzeb, dążeń i celów życiowych jednostki w obszarze najbardziej cenionych przez nią wartości. Orientacja życiowa jest wypadkową wielu czynników: doświadczeń życiowych, zakresu i rodzaju wiedzy, motywacji, umiejętności działania, typu osobowościowego, stylu poznawczego, nastawień oceniająco-wartościujących, czynników środowiskowych. Orientacje życiowe rozwijają się stopniowo w miarę nabywania przez jednostkę nowych dyspozycji życiowych. 
logicznie nasycone i etycznie zaangażowane oraz zakorzenione w subiektywności, która w fenomenologicznej perspektywie poznawczej Edmunda Husserla jest źródłem wszelkiej obiektywizacji. Są także dynamiczne i procesualne, bo nie powstają w jednorazowym akcie wyłonienia się, ale wciąż przedstawiają się, kształtują się i zmieniają przez całe życie człowieka. Ze swej istoty pozostają permanentnie niedokończone, transcendentalne w sensie możliwym i transgresyjne w wymiarze koniecznym. Zawsze wiążą się z przekraczaniem ograniczeń, wyzwalaniem „od” i dążeniem „do”. Mają charakter emancypacyjny i dialogiczny, kształtują się w relacji człowieka ze światem, w procesie zdobywania podmiotowości i wolności, $\mathrm{w}$ dialogu z Innym.

Twórcza orientacja życiowa nie musi przejawiać się w formie wytwórczej, jej miarą nie jest wytwór, chociaż może być on jej istotnym elementem. Urzeczywistnianie twórczej orientacji życiowej staje się możliwe, gdy jednostka podda się imperatywowi działania i ujawni się „fenomen wolności”, czyli wyzwolenie od dotychczasowych ograniczeń i wolność do stworzenia czegoś nowego. Aby mogła się ona zrealizować, trzeba dostrzec rzeczywistość w perspektywie fenomenologicznej, gdzie zwykła rzecz przedstawia się jako fenomen. Zdolność widzenia inaczej należy bowiem do istoty twórczego podmiotu. Człowiek kreuje swoje życie wtedy, kiedy widzi jego stan aktualny, ale na tym nie poprzestaje. Dostrzega możliwości zmiany we własnym życiu, kształtowania go, a co za tym idzie podejmuje wyzwania i poddaje się imperatywowi działania. Staje więc na drodze osiągania osobistej wolności przez dostrzeganie tego, co jest, tego, co można zmienić i tego, co w wyniku owej zmiany może się dokonać.

Na podstawie ustaleń psychologii twórczości dotyczących specyficznych cech osób twórczych w różnych dziedzinach i zakresach, a także własnych badań i analiz w tym obszarze przypuszczam, że osoby o twórczej orientacji życiowej:

- są lepiej przygotowane do funkcjonowania w złożonej, dynamicznej rzeczywistości, w społeczeństwie otwartym, bowiem to co nowe i nieznane wywołuje w nich przede wszystkim potrzebę uczenia się, poznawania i doświadczania;

- charakteryzuje je autonomiczna motywacja poznawcza, w której ciekawość i pragnienie nowych doświadczeń ukierunkowuje działanie;

- akceptują zmianę jako coś naturalnego, aprobują różnice, potrafią harmonijnie łączyć przeciwstawne cechy; 
- sprawniej spostrzegają rzeczywistość, dzięki umiejętności dostrzegania konkretów, uogólniania, abstrahowania, klasyfikowania, a także świeżości spojrzenia;

- są zdolne do pełnej koncentracji nad jakąś sprawą i przeżywania stanu zafascynowania danym problemem.

\section{Założenia holistycznej koncepcji edukacji międzykulturowej}

Holistyczne ujęcie edukacji międzykulturowej zaproponowane i rozwijane przez Jerzego Nikitorowicza bazuje na modelu rozwoju wrażliwości międzykulturowej Miltona J. Bennetta [Nikitorowicz 2005]. Sytuuje się ono w drugim, z wyróżnionych przez Bennetta, etapie jej kształtowania się, w którym dochodzi do akceptacji różnic w wartościach i zachowaniu Innego. Przy czym, w edukacji międzykulturowej wydaje się to niewystarczające. Konieczne jest, w moim przekonaniu, twórcze rozumienie odmienności w znaczeniu, jakie nadał temu Bachtin w swojej antropologii filozoficznej. Dokonuje się ono w wielopodmiotowym dialogu, w "polifonicznej” przestrzeni wielu głosów. Sens tego dialogu zawiera się we „współodpowiadaniu"; każda wypowiedź jest odpowiedzią na inną, czasem nawet bardzo odległą. Wszystkie głosy w tej przestrzeni dialogicznej są równoprawne. Mądrość bowiem, w myśl tego stanowiska filozoficznego, nie jest dana jednemu człowiekowi raz na zawsze, ale rodzi się w poszukiwaniu, we wzajemnym współistnieniu wielu racji, poglądów i przekonań. Pełniejsze zrozumienie rzeczywistości jest możliwe w różnorodności i wielości stanowisk, a nie w homofonii, choć ta ostatnia zapewne jest wygodniejsza. „Polifoniczne” pogranicze stwarza więc szansę na kształtowanie pełnej wrażliwości postawy etycznej i aksjologicznej, zakłada supozycję „dobrej woli” Innego, sprzyja twórczemu rozumieniu odmiennych stanowisk poznawczych, etycznych i estetycznych [Bachtin 1986; 1970; 1982; 1983].

Edukacja międzykulturowa w swym holistycznym ujęciu podejmuje wiele problemów związanych z dostrzeganiem wartości w innych, odmiennych kulturach, mimo własnych nawyków i przyzwyczajeń, z kształtowaniem otwartej tożsamości młodych ludzi, z wypracowaniem takich działań, które nie dopuszczą do rozwoju agresywnego etnocentryzmu [Nikitorowicz 2005]. Dodałabym do tego katalogu także podjęcie wyzwania kształtowania i rozwijania w procesie edukacji międzykulturowej twórczych orientacji życiowych, sprzyjających, jak wynika z niniejszej narracji, otwartości na 
odmienność, jej rozumieniu i poszanowaniu, bez zatracania własnej perspektywy kulturowej, oraz dialogicznemu współistnieniu z Innym.

Za pierwszoplanowe zadanie holistycznie rozumianej edukacji międzykulturowej uznaje się prowadzenie dialogu kultur, „a przede wszystkim dialogu kultury lokalno-regionalnej z kontynentalno-planetarną" [Nikitorowicz 2005: 203]. Wiąże się ono bezpośrednio z kształtowaniem postawy szacunku wobec odmienności kulturowej, wzajemnego uznania wartości, czyli kreowania postawy tolerancji przy jednoczesnej ochronie „świata zakorzenienia" jednostki poprzez zachowanie pamięci o przodkach i bliskich oraz łączenia jej z teraźniejszością i przyszłością, a także „poszukiwaniem możliwości pokojowego współistnienia kultur” [Nikitorowicz 2005: 203]. W tym ujęciu edukacji międzykulturowej szczególne znaczenie przypisuje się kulturze rodziny, grupy familijnej, społeczności lokalnej i parafialnej jako nośników niezbywalnych wartości konstruujących podstawy tożsamości jednostki. Za priorytet uznaje się „zauważenie i podjęcie próby zrozumienia inności kulturowej poprzez akceptację i zrozumienie własnej" [Nikitorowicz 2005: 204]. Edukacja międzykulturowa jest tu rozumiana jako ustawiczny proces dialogu kultur, w którym podmioty dążą do wzajemnego poznawania się i zrozumienia, zbliżenia emocjonalnego, współdziałania i wspierania się. Kształtuje ona tożsamość międzykulturową, która łączy indywidualne i społeczne, rodzinne, lokalne i globalne, uniwersalne aspekty autoidentyfikacji. Samookreślenie dokonuje się tu w procesie identyfikowania się z określonymi wartościami rdzennej grupy oraz z wartościami kolejnych grup przynależności. Jest to zatem ewolucyjne ujęcie, w którym opisuje się swoiste przejście do uniwersum lokalnego do globalnego, przy zachowaniu świadomości własnej odrębności, „od tożsamości rodzinno-parafialnej, lokalnej regionalnej, poprzez narodową, państwową ku kontynentalnej, planetarnej” [Nikitorowicz 2005: 205].

Zadaniem edukacji międzykulturowej jest także, w tym ujęciu, kształtowanie potrzeby korzystania $\mathrm{z}$ własnego dziedzictwa kulturowego, w które każda jednostka wrasta od chwili narodzin. Szacunek do niego, zaakceptowanie go i ustawiczne wzbogacanie jest swoistym zabezpieczeniem przed unifikującym wchłonięciem i zagubieniem w globalnym tyglu masowej kultury, ale także warunkiem obcowania, współistnienia z innymi kulturami, nawiązania z nimi dialogu. Obok tego niezbędne jest też uświadamianie istnienia uniwersaliów wspólnych dla wszystkich ludzi, niezależnie od tego, w jakich kulturach się wychowali. Należą do nich potrzeby biologiczne, socjalno-bytowe, psychiczne i społeczne, podobne dla całego gatunku ludzkiego. Sprzyja to kształtowaniu szacunku wobec wartości uniwersal- 
nych, postawy otwartości i wrażliwości na Innego oraz uczy troski o dobro drugiego człowieka, którego odmienność nie jest zagrożeniem dla „ja”, ale szansą na wzbogacenie przeżyć, zdobycie nowych doświadczeń. Taka postawa jest wpisana także $w$ twórcze orientacje życiowe, które sprzyjają angażowaniu się w działania na rzecz wspólnego dobra.

Uznanie i tolerancja odmienności kulturowych staje się we współczesnym świecie szczególnie ważną wartością i zadaniem edukacji. Konieczne jest wypracowanie takich strategii edukacyjnych, które rozwijają odpowiednie kompetencje i postawy kulturowe. Kształtują poczucie podmiotowości, wolności, sprawstwa i odpowiedzialności, ale także solidarności i integracji z Innymi w uniwersum ogólnoludzkich wartości. Zatem zadaniem edukacji międzykulturowej jest podejmowanie działań na rzecz wyeliminowania niechęci i uprzedzeń wobec Innego, Obcego. Kształtowanie postawy szacunku dla jego indywidualności i godności, jego wolności i uprawnień. Promowanie paradygmatu współistnienia i wzajemnego rozwoju w wyniku porozumienia, negocjacji i kooperacji. Jednym z czterech podstawowych filarów edukacji jest dzisiaj bowiem "uczyć się, żeby żyć wspólnie” [Raport... 1998].

W holistycznej koncepcji edukacji międzykulturowej podkreśla się znaczenie kilku czynników sprzyjających realizacji jej założeń. Jednym z nich jest unikanie w procesach edukacyjnych arbitralności, uwzględniania kultury różnych grup, regionów bez ich oceniania i kategoryzowania. Bardzo istotne jest łączenie w procesie kształcenia i wychowania elementów kultury rodzinnej, regionalnej z elementami kultury narodowej, europejskiej i światowej. Kolejnym czynnikiem niezbędnym w edukacji międzykulturowej jest świadome podejmowanie dialogu kulturowego i wychodzenie poza ramy własnej grupy odniesienia z zamiarem poznania i zrozumienia odmienności oraz życzliwe ustosunkowanie do nich. Podkreśla się też znaczenie refleksyjności i samoświadomości połączonej z wiedzą, płynącą z kontaktów społecznych, porównań z innymi ludźmi, rozumienia perspektywy Innego. Niezmiernie ważne jest w tych procesach edukacyjnych zdobywanie wiedzy na temat historii, tradycji i wartości swojej grupy oraz innych grup kulturowych. Konieczne jest także nabywanie kompetencji komunikowania się w rodzimym języku i w języku innej, sąsiedniej grupy kulturowej, w przestrzeni zróżnicowania kulturowego. Nie mniej istotna jest gotowość do wchodzenia w relacje wielokulturowe, z życzliwością dla Innego, chęcią jego poznania [Nikitorowicz 2005]. 


\section{Zakończenie i nowe otwarcie}

Poszukiwanie wspólnych obszarów narracji autorskiej koncepcji twórczych orientacji życiowych i holistycznej koncepcji edukacji międzykulturowej Jerzego Nikitorowicza doprowadziło do wskazania kilku ich aspektów. Pierwszym, wyeksponowanym na początku niniejszego artykułu, jest swoista wspólnota założeń ontologicznych tkwiących u podstaw konstruowania tych koncepcji. Obie bowiem wpisują się w dialogiczne ujęcie istoty funkcjonowania człowieka w świecie, w antropologię filozoficzną eksponującą bycie podmiotu w polifonicznej przestrzeni pogranicza wielu kultur.

Znamienne jest także sytuowanie się obu koncepcji w metafizyce orientacji, w której punktem wyjścia dla budowania obrazu świata i poszukiwania kierunku działania jest praktyka życia człowieka. Czasowość człowieka, konkretność zdarzeń, zjawiska zwyczajne stanowią podstawę budowania nowej filozofii, w której poszukiwanie prawdy przeradza się w poszukiwanie orientacji. Dokonuje się więc tu przejście od abstrakcyjnego świata teoretycznego do żywego świata odpowiedzialności [Szulakiewicz 2003], od teorii poznania przez antropologię filozoficzną do filozofii dialogu, która za swój fundament przyjęła etykę i w codzienności każe poszukiwać orientacji [Walczak 2007]. Wymaga to stałej otwartości na rzeczywistość, która objawia się nam w postaci Innego [Bachtin 1992; Buber 1991; 1992; Gadamer 1993; Lévinas 2002; Tischner 1993].

Istotna $\mathrm{w}$ obu podejściach jest też perspektywa pedagogiki humanistycznej i emancypacyjnej, gdyż eksponowany jest w nich szacunek i godność każdej osoby, jej podmiotowe zakorzenienie w świecie oraz prawo do wolności. Kompetencje i racjonalność emancypacyjna wydają się znaczące zarówno w kontekście kształtowania twórczego stosunku do życia, jak i w aspekcie wyzwolonego ze stereotypów i niechęci postrzegania Innego.

Znaczącą kategorią w obu koncepcjach, jest też, w moim przekonaniu, kategoria twórczego rozumienia odmienności, akcentująca konieczność zachowania własnej perspektywy kulturowej, która umożliwia poznanie odmienności, jej akceptację, zrozumienie i wzbogacenie własnego spojrzenia na świat. Dokonuje się zatem ewolucyjny powrót do siebie, ale już innego, bogatszego o nowe sensy istnienia zdobyte dzięki współbyciu z Innym. Zalecenia i zadania edukacji międzykulturowej wyeksponowane w końcowej części analizy są także bardzo ważne w stwarzaniu jednostce warunków kształtowania twórczego stosunku do życia, wyrażającego się w twórczych orientacjach życiowych. 
Rysunek 1. Wspólne obszary narracji koncepcji twórczych orientacji życiowych i holistycznej koncepcji edukacji międzykulturowej

\begin{tabular}{|c|c|}
\hline $\begin{array}{c}\text { Metafizyka orientacji } \\
\text { i filozofia dialogu }\end{array}$ & $\begin{array}{c}\text { Pedagogika } \\
\text { humanistycznai } \\
\text { emancypacyjna }\end{array}$ \\
\hline Otwartość na Innego & $\begin{array}{c}\text { Twórcze rozumienie } \\
\text { Tólacji z Innym }\end{array}$ \\
\hline
\end{tabular}

TOŻ: Koncepcja twórczych orientacji życiowych; HEM: Koncepcja holistyczna edukacji międzykulturowej

Źródło: opracowanie własne.

Obie analizowane tu koncepcje mają też swoje empiryczne egzemplifikacje, jednak opisywanie ich wykracza poza ramy tego opracowania, chociaż może być ciekawym przedsięwzięciem. Interesujące byłoby poddanie weryfikacji hipotezy dotyczącej relacji między działaniami edukacyjnymi podejmowanymi przez nauczycieli w zakresie edukacji międzykulturowej a ich preferencjami dla twórczych orientacji życiowych.

\section{Bibliografia}

Bachtin M. (1986), Estetyka twórczości słownej, przeł. D. Ulicka, Warszawa

Bachtin M. (1970), Problemy poetyki Dostojewskiego, przeł. N. Modzelewska, Warszawa

Bachtin M. (1982), Problemy literatury i estetyki, przeł. W. Grajewski, Warszawa

Bachtin M. (1983), Dialog - język - literatura, Warszawa

Bibler W. (1992), Myślenie jako dialog, przeł. i wstęp J. Dobieszewski, Warszawa

Buber M. (1991), O Ja i Ty, [w:] B. Baran (red.), Filozofia dialogu, Kraków

Buber M. (1992), Ja i Ty: wybór pism filozoficznych, wybór, przeł. i wstęp J. Doktór, Warszawa

Craft A. (2000), Creativity Across the Primary Curriculum, London and New York

Cudowska A. (1997), Orientacje życiowe współczesnych studentów, Białystok

Cudowska A. (2004), Kształtowanie twórczych orientacji życiowych w procesie edukacji, Białystok

Cudowska A. (2014), Twórcze orientacje życiowe $w$ dialogu edukacyjnym. Studium teoretyczno-empiryczne, Białystok

Czerepaniak-Walczak M. (2006), Pedagogika emancypacyjna. Rozwój świadomości krytycznej człowieka, Gdańsk 
Gadamer H. G. (1993), Prawda i metoda. Zarys hermeneutyki filozoficznej, przeł. B. Baran, Kraków

Kłoskowska A. (1964), Kultura masowa. Krytyka i obrona, Warszawa

Korniłowicz K. (1976), Pomoc w tworzeniu jako zadanie pracy kulturalnej, [w:] O. Czerniawska (red.), Pomoc społeczno-kulturalna dla młodzieży pracującej i dorosłych. Wybór pism, Wrocław.

Kozielecki J. (1987), Koncepcja transgresyjna człowieka, Warszawa

Kozielecki J. (1997), Transgresja i kultura, Warszawa

Kozielecki J. (2001), Psychotransgresjonizm. Nowy kierunek psychologii, Warszawa

Lévinas E. (2002), Całość i nieskończoność. Esej o zewnętrzności, przeł. M. Kowalska, Warszawa

Modrzejewska-Świgulska M. (2007), Teorie twórczości codziennej, [w:] K. J. Szmidt, Pedagogika twórczości, Gdańsk

Nikitorowicz J. (2005), Kreowanie tożsamości dziecka: wyzwania edukacji międzykulturowej, Gdańsk

Radlińska H. (1979), Oświata i kultura wsi polskiej: wybór pism, Warszawa

Raport dla UNESCO Międzynarodowej Komisji do spraw Edukacji dla XXI wieku pod przewodnictwem Jacques'a Delorsa. Edukacja. Jest w niej ukryty skarb (1998), Warszawa

Richards R. (1999), Everyday Creativity, [w:] M. A. Runco, S. R. Pritzker (red.), Encyclopedia of Creativity, San Diego

Richards R. i in. (1997), Creativity in manic-depres-sives cyclothymes their normal relatives, ans control subjects, [w:] R. Richards, M. A. Runco (red.), Eminent Creativity, Everyday Creativity and Health, London

Runco M. A. (2005), Creativity Giftedness, [w:] R. J. Sternberg, J. Davidson (red.), Conceptions of Giftedness, Cambridge

Runco M. A. (2006), Reasoning and personal creativity, [w:] J. C. Kaufman, J. Bear (red.), Creativity and Reason in Cognitive Development, Cambridge

Schnädelbach H. (2001), Próba rehabilitacji animals rationale, przeł. K. Krzemieniowa, Warszawa

Słownik współczesny języka polskiego (1998), t. 2, Warszawa

Szmidt K. J. (2002), Wcześniej niż Fromm i Maslow: Korniłowicza i Radlińskiej koncepcje postawy twórczej na tle współczesnym, [w:] K. J. Szmidt i K. T. Piotrowski (red.), Nowe teorie twórczości. Nowe metody pomocy w tworzeniu, Kraków

Szulakiewicz M. (2003), Dialog jako podstawa metafizyki. Od metafizyki fundamentu do metafizyki orientacji, [w:] J. Baniak (red.), Filozofia dialogu, t. 1, Poznań

Świgulska M. (2009), Twórczość w wymiarze egalitarnym - krytyczna prezentacja stanowisk, [w:] S. Popek i in. (red.), Psychologia twórczości. Nowe horyzonty, Lublin

Tischner J. (1993), Myślenie według wartości, Kraków

Tischner J. (2000), Świat ludzkiej nadziei, Kraków

Walczak P. (2007), Wychowanie jako spotkanie. Józefa Tischnera filozofia człowieka jako źródło inspiracji pedagogicznych, Kraków 


\section{SUMMARY}

\section{Openness Toward Other. Innovative Life Orientation in the Project of Intercultural Education}

In the following article author presents the theoretical assumptions of the concept of creative life orientation, the specificity of creative life orientation, and the theoretical assumptions of the concept of holistic intercultural education. This article presents the collaborative areas of both concepts: ontological assumptions in philosophy of dialogue, metaphysics of orientation, human pedagogy and empirical research as exemplification of these concepts. Openness to Another, dialogue with Him and creative understanding of Another are very important in the concept of creative life orientation and in the concept of holistic intercultural education.

\section{Keywords:}

religiously mixed marriage, religion, secularization, acculturation 